\title{
Improving measurement of household savings and wealth
}

\section{SUMMARY}

This article describes recent trends in household saving and wealth leading up to the current economic downturn. It focuses specifically on the saving ratio and the contributions of pensions in household wealth. Although National Accounts measures have provided good indicators of the imbalances that developed in the years before the financial crisis, a number of improvements have been identified - which should become possible in the future using information from new household survey sources. These include breaking down household debt demographically, for which it is planned to publish new analyses and datasets in late 2009.
his article looks at issues affecting the household sector in the build-up to the financial crisis which hit the UK in 2008 (see Box $\mathbf{1}$ for a description of the household sector). In particular, it discusses measures of household saving, wealth and debt in the National Accounts, and asks how effective these measures were in documenting the imbalances that developed in the years before the crisis. In some areas, it finds that the measures available in the National Accounts provided good indicators which gave policymakers helpful information as the imbalances developed. In others, the measures could be improved - and this should become possible in future using information sourced from new household surveys.

One particular area of development, for which there is heavy demand, is a demographic breakdown of household debt. Initial analyses and datasets providing this are planned for publication in late 2009, further details of which are given at the end of this chapter.

\section{Household income, consumption and savings}

In the household sector of the National Accounts, income and consumption expenditure of households are estimated directly from data sources such as Her Majesty's Revenue and Customs (HRMC), Pay As You Earn (PAYE) data, the Annual Business Inquiry (ABI), the Living Costs and Food Survey (LCFS) and the Retail Sales Inquiry (RSI).

However, estimates of household savings are not calculated directly. Instead, they are calculated as household resources minus final household consumption and expenditure. (Household resources are the sum of gross disposable household income and the adjustment for the change in net equity of households in pension funds). Thus, the estimates of household savings in the National Accounts are calculated as a residual - the difference between disposable income and final consumption expenditure. The quality of the savings estimates is dependent on the quality of the components used to calculate the residual. In addition, data for these components in the latest two or three quarters are always liable to revision.

Despite the indirect method of calculating household savings, they did act as an early indicator of problems looming in the economy in the run-up to the 2008 financial crisis. The indicator came in the form of the household saving ratio which is household savings as a percentage of total household resources. The household saving ratio increases if the household spends less or has more resources available. It decreases if the household spends more as a percentage of its resources. This can be done by borrowing (increasing debt) or drawing down on assets (for example, households withdrawing equity from their houses), allowing the household to increase consumption without increasing income, thus producing a decline in the saving ratio.

During the last decade, the UK has seen big increases in household spending relative to total resources, and the saving 


\section{Box 1}

\section{The household sector in the National Accounts}

A household is a group of people collectively taking responsibility to feed and house themselves. The majority of households consist, essentially, of one, two or more people living under one roof usually linked by family ties. However, there are also 'institutional' households - people living in communal establishments such as care homes, or those detained in prison. The household sector of the National Accounts contains institutional households as well as family units.

There are two further complications. First, households can also run family businesses such as a shop, a self-employed builder or taxi firm, known as unincorporated enterprises. Such businesses also contribute to the household sector accounts. While it is possible to separate some transactions between 'pure' households and unincorporated enterprises from the statistics currently available, it is impossible to do this for income transactions. Hence no complete accounts exist for 'pure' households or for unincorporated enterprises. This means it is not possible, from a National Accounts perspective, to measure saving or wealth for 'pure' households on their own.

Second, non-profit institutions serving households (NPISH), such as charities and housing associations, are included in the household sector. While it is possible, in theory, to separate out the NPISH sector, this has not been done in the UK National Accounts and some changes would be required to sampling and estimation methods to provide all the necessary data. However, it should be noted that the contribution of the NPISH sector is small compared to the rest of the household sector. ratio fell to 2.2 per cent in 2007 and 2.0 per cent in 2008 (see Figure 1). The fall in the saving ratio since the mid-1990s probably reflects growth in household borrowing to finance personal consumption and property purchases during the long run of economic prosperity and financial diversification leading up to the 2008 financial crisis.

However, there are a number of other factors which can cause households to spend more and save less. In the UK, strong economic growth, low unemployment, low inflation, easy access to credit at low interest rates and strong house prices all contributed to the spending boom. Saving for the future became less of a necessity for many people as their assets were increasing to cover additional expenditure, and borrowing more money at low interest rates was increasingly easy.

The declining saving ratio could be seen as an early indicator of problems in the economy, as it suggested unsustainable levels of household consumption financed primarily by increasing debt. Households were vulnerable to a sharp reduction in the availability of cheap credit and by falling house prices. When the financial crisis hit in 2008, this vulnerability became a real weakness, and households reacted by reining in expenditure, which contributed to the economic downturn.

However, using the saving ratio to predict a crisis in the UK economy is difficult because National Accounts data have limitations when it comes to economic analysis. As previously mentioned, a key weakness of the National Accounts definition of the household sector is the inability to separate the 'pure' household from the self-employed person or small business. While it can be argued that the two are inextricably linked, it should also be noted that economic conditions and policies will have a differing impact on 'pure' households as compared to small business units.

\section{Household sector balance sheets}

Gross household wealth is the value of accumulated assets. Net household wealth is the value of accumulated assets minus the value of accumulated liabilities. In the National Accounts, net wealth is referred to as net worth.

The main household sector assets are financial assets (for example currency and deposits, shares and other equity, and net equity in life assurance and pension funds) and non-financial assets (mainly residential buildings). The main liabilities of the household sector are loans secured on buildings (mainly mortgages).

The National Accounts balance sheets are produced quarterly and annually, and they include the combined household and NPISH sector. For many transaction lines, such as pensions or life assurance, the household sector has no source of data and the value which is allocated is a mirror (counterparty) of an entry for another sector or a residual after the data for other sectors have been subtracted from an estimated total. For example, the estimate for net equity in life assurance and pension funds - in financial assets - is based on the value of assets held by insurance companies and pension funds themselves, which is recorded in the corporate sector. For this reason, revisions can often be seen in the household data when a counterparty sector revises data.

Work is ongoing within ONS to identify new sources of household data to be used within the National Accounts and the first area likely to report findings during 2010 will be the transaction line for unquoted shares. Unquoted shares are those which are not listed on a stock exchange and are primarily held by owners of small businesses as part of the household sector. Unquoted shares are very difficult to put a value on but a number of methods and data sources are currently being investigated which will hopefully lead to a data source for the household element rather than the current residual approach.

The information on household sector

\section{Figure 1}

\section{Household saving ratio}

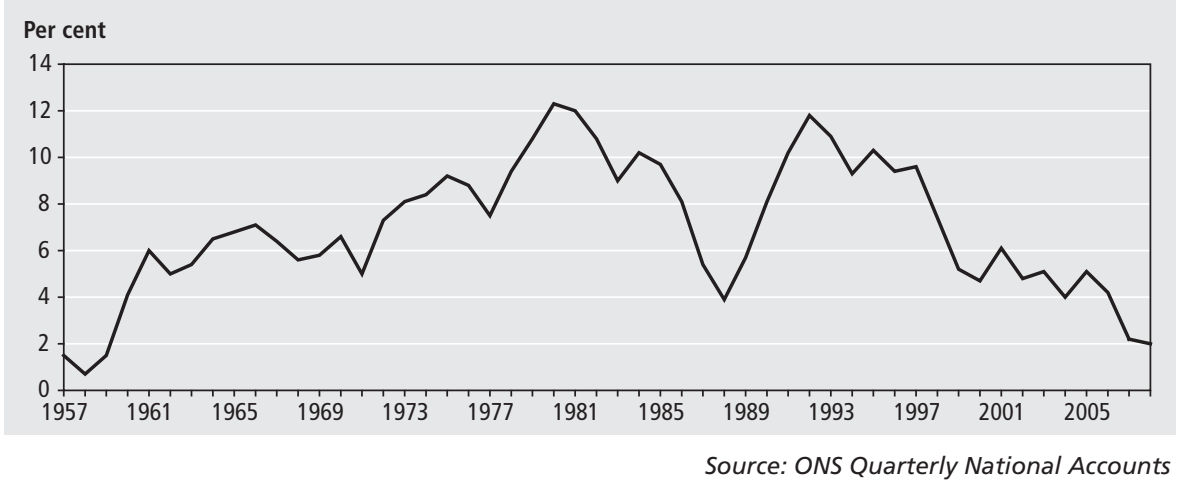


assets and liabilities can be used to look at household wealth, and also to track unusual changes - such as sharp increases in household debt - which help to indicate potential imbalances in the run-up to a crisis.

\section{Household debt}

Figure 2 shows that since the mid-1990s households have experienced big increases in debt as a percentage of GDP in the form of short-term loans, mainly consumer credit, and long-term loans, mainly mortgages.

While there is a need to produce collected measures of household debt, there is also a clear demand for breakdowns by gender, age, income group or region. Although, National Accounts data sources cannot support such analyses at present, the ONS is currently engaged in a joint project with Bristol University to provide a more comprehensive picture of the household sector.

\section{Pensions in household wealth}

One of the key financial assets of the household sector is net equity in life assurance and pension funds. In 2007 this category made up over half of households' total financial assets, and 29 per cent of their net worth (defined as household financial assets minus household financial liabilities plus household non-financial assets). Figure 3 shows households' net equity in life assurance and pension funds as a percentage of GDP. It rose rapidly for most of the 1990s, but dropped back sharply with the falls in equity values in the early 2000s. As a proportion of GDP, household assets in life assurance and pension funds peaked in 1999 at 176 per cent of GDP ( $£ 1.6$ trillion). By 2007 they were 156 per cent of GDP ( $£ 2.2$ trillion).

The data used to compile the series net equity in life assurance and pension funds in the National Accounts are reported on a quarterly basis, and are considered reliable because they come from the ONS published series: Investment by Insurance Companies, Pension Funds and Trusts (MQ5), which takes information from the accounts of pension providers. However, it is not possible to separately identify household pension assets in the National Accounts, as many pensions are provided by insurance companies, which do not report their pensions business separately from insurance business.

It should be noted that the methodology used to construct the National Accounts means that the aggregate liability of insurance companies and pension funds (calculated from their total liabilities less any identified liabilities such as borrowing, and appearing in the corporate sector accounts) is equal to the market value of their net assets, but not necessarily equal to the actuarial value of their pension liabilities. There is, therefore, no official estimate of the pension fund 'shortfall' that occurs where aggregate liabilities of defined benefit pension schemes (based on actuarial values) are higher than their assets.

In addition, the pension wealth shown in the National Accounts is only for funded pensions, which consist of private sector occupational pension schemes, employersponsored personal pensions and the local government pension scheme for local authority employees. The National Accounts do not show assets or liabilities of unfunded or 'pay as you go' pension schemes covering state pensions and public service pensions for the civil service, armed forces, National Health Service (NHS), teachers, police and fire fighters. This is because there are no funds to record as liabilities.

However, work is currently being undertaken on a new revision of the System of National Accounts (SNA) to replace SNA 1993. It is anticipated that the new revision will include as liabilities, estimates of the future pension benefits payable by state social security schemes and unfunded public sector occupational pension schemes. However, it is not clear on what basis such liabilities would be estimated. The European System of Accounts (ESA) 1995 is also undergoing revision, and a separate decision will be made as to the relevance and feasibility of recording such liabilities in the revised ESA, and whether they would appear in the core ESA-based National Accounts or - as is more likely - in a supplementary table. The UK will introduce the revised ESA in 2014.

\section{Improving measures using survey sources}

HMRC (formerly the Inland Revenue) has published statistics on the distribution of personal wealth held by residents of the UK since 1962. These statistics are based primarily on the 'estates multiplier' method. Broadly speaking, they make use of the information about individuals' assets revealed from the probate or Inheritance Tax process to provide estimates of the wealth held by the living. There are serious limitations to this method, in particular the exclusion of pension wealth. Problems with the methodology in recent years mean that the latest data available relate to 2003 .

The need for improved measures of wealth has been noted for some time. This has resulted in the creation of a new survey,

\section{Figure 2 \\ Household sector financial liabilities (debt)}

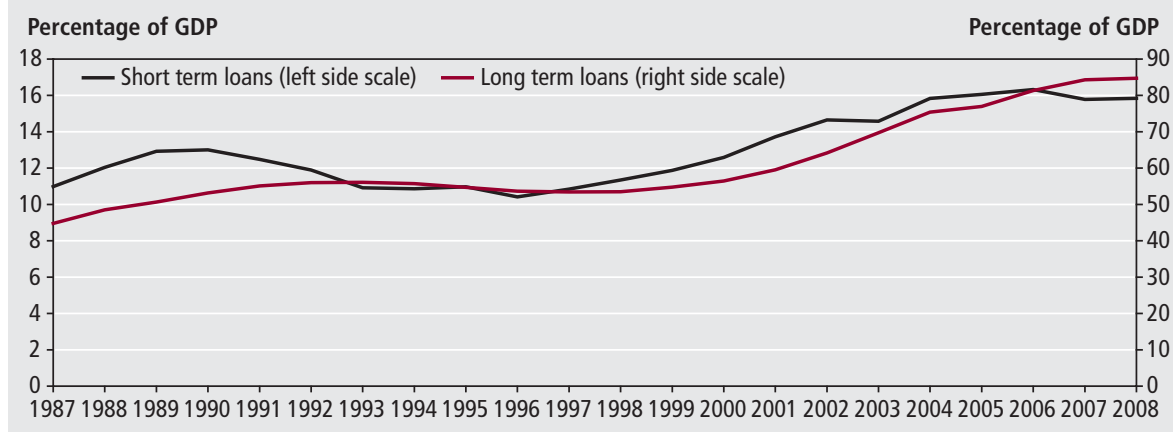

Source: ONS Quarterly National Accounts

\section{Figure 3}

\section{Household assets in life assurance and pension fund reserves}

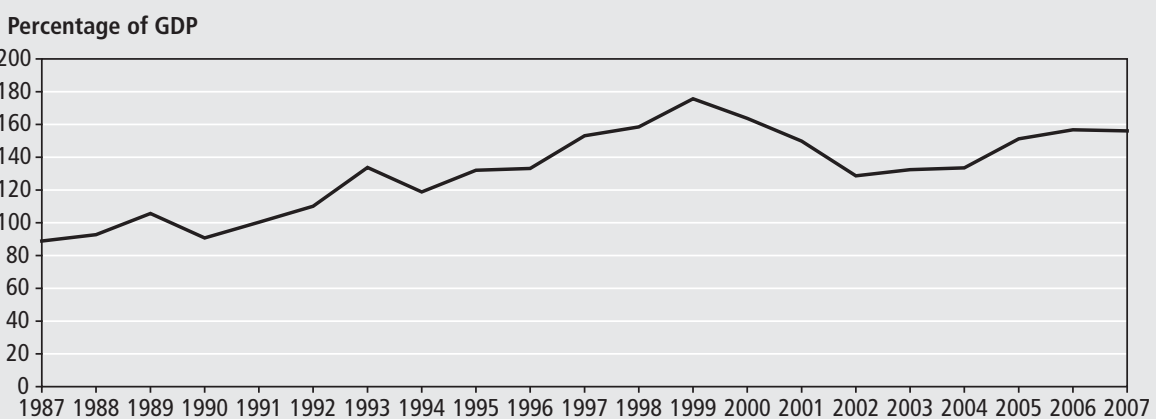


the Household Assets Survey (HAS). The HAS was specifically designed to produce measures of household and personal wealth. The HAS is a longitudinal sample of 32,000 households surveyed over a period of two years. The first wave of collection covers the period July 2006 to June 2008 . Wave II, covering the period July 2008 to June 2010, is currently in the field.

The Household Assets Survey collects information on household assets and liabilities and is designed to produce estimates of household wealth, comprising property and other physical assets, financial and pension wealth.

The first main results covering the period July 2006 to June 2008 (Wave I) will be available towards the end of 2009. Results of Wave II, covering the period July 2008 to June 2010, will be available in 2011. In the interests of timeliness, the analysis will be primary in nature, presenting a summary of the data, but without comparisons with other sources. Such comparisons, however, will be an important aspect of the quality assurance of the dataset. The 2009 report will be the mechanism for placing the data into the public domain, and will be the springboard for collaborators to work with the data on their own detailed secondary analyses. Further analysis of the data will be done after publication of the 2009 report that will look at more detailed aspects of the data, for instance work is planned with HMRC to look at how better estimates of wealth can be produced by combining HAS and HMRC data.

The 2009 main report will include analysis of the assets, liabilities and net wealth of households. There will be chapters looking in detail at household property wealth (including mortgages), household financial wealth (including formal and informal savings, children's assets), private pensions (including current and deferred pensions, modelling of accrued pension entitlements, excluding state pensions) and household physical wealth such as household goods and collectibles. Each chapter will include distributional properties of net wealth by different social and demographic characteristics such as age, socio-economic classification and place of residence. These analyses will be compared with household sector information used in the National Accounts and will be used to improve National Accounts measures of saving and wealth.

There will also be a chapter looking at household debt, particularly non-mortgage borrowing and arrears. Non-mortgage borrowing is defined as the use of any credit or store cards that are not settled in full each month, overdrafts and all forms of fixed-term loans, including personal loans, hire purchase agreements and mail order accounts. There will also be a chapter on people's attitudes to saving, borrowing and retirement. In particular, there is interest in how these relate to each other (such as attitudes towards debt and towards savings, attitudes to pensions and attitudes to savings, risk, etc.), as well as how the attitudes relate to actual behaviours.

The survey also includes a follow-up survey looking at indebted households in more detail, based on a sub-sample of households from Wave I. The follow-up survey started in October 2007, so will cover eligible households from HAS which were interviewed between October 2006 and June 2008. These households form a population that may be described as households at risk of financial exclusion, meaning they are likely to face constraints in accessing credit.

\section{CONTACT}

elmr@ons.gsi.gov.uk 